\title{
Determinan Perilaku Seksual Pada Remaja
}

\author{
Hafidhatul Aina ${ }^{1}$, Siti Masyitah, Laila ulfa \\ Program Studi Ilmu Kesehatan Masyarakat, Program Pascasarjana, \\ Universitas Respati Indonesia \\ Email: ainahafi@yahoo.com
}

\begin{abstract}
Abstrak
Remaja adalah masa perubahan dari masa anak menuju dewasa dan perilaku kaum remaja mencoba hal baru yang di dapatnya terutama dari rangsangan seksual. Survei Litbang Kesehatan bekerjasama dengan UNESCO tahun 2018, memberikan data remaja Indonesia melakukan seks bebas pranikah sebanyak 5,6\%. Survei pendahuluan dilakukan pada 20 siswa di SMK Bhakti Bangsa ada 80\% siswa berpacaran dan melakukan perilaku seksual. Penelitian ini bertujuan mengetahui dan menjelaskan determinan perilaku seksual pada remaja. Metode penelitian ini merupakan penelitian kuantitatif dengan menggunakan rancangan cross sectional. Pengumpulan data dengan menggunakan kuesioner. Populasi dalam penelitian ini yaitu 306 siswa dengan jumlah sampel 174 siswa yang diambil secara accidental sampling. Pengolahan data mengunakan analisis data univariat, bivariat dan multivariat. Hasil chi square ada hubungan yang signifikan antara variabel pengetahuan, media informasi, peran orang tua dan pengaruh teman sebaya dengan perilaku seksual remaja. Hasil uji regresi logistik menunjukkan bahwa variabel media informasi merupakan variabel yang paling dominan terhadap perilaku seksual. Remaja yang terpapar dengan media informasi berpeluang 2,3 kali melakukan perilaku seksual yang beresiko. Kesimpulan pada penelitian ini yaitu paparan media informasi berperan penting terhadap perilaku seksual yang beresiko pada remaja.
\end{abstract}

Kata Kunci : Perilaku seksual; Remaja

Daftar Pustaka : 123 (1992-2019)

\begin{abstract}
Adolescence is a period of change from childhood to adulthood and the behavior of adolescents to try new things that they get, especially from sexual stimulation. The Health Research and Development Survey in collaboration with UNESCO in 2018, provided data on Indonesian teenagers engaging in premarital sex as much as $5.6 \%$. The preliminary survey was conducted on 20 students at SMK Bhakti Bangsa, where $80 \%$ of students are dating and engaging in sexual behavior. This study aims to identify and explain the determinants of sexual behavior in adolescents. This research method is a quantitative study using a cross sectional design. Data collection using a questionnaire. The population in this study were 306 students with a sample size of 174 students who were taken by accidental sampling. Data processing used univariate, bivariate and multivariate data analysis. The chi square results showed a significant relationship between the variables of knowledge, information media, the role of parents and peer influence with adolescent sexual behavior. The logistic regression test results show that the information media variable is the most dominant variable on sexual behavior. Teens who are exposed to information media have a 2.3 times chance of engaging in risky sexual behavior. The conclusion in this study is that exposure to information media plays an important role in risky sexual behavior in adolescents.
\end{abstract}

Keywords: Sexual behavior; Youth

http://ejournal.urindo.ac.id/index.php/kesehatan

Article History :

Sumbitted 11 September 2020, Accepted 30 Desember 2020, Published 31 Desember 2020 


\section{Jurnal Bidang Ilmu Kesehatan}

Bibliography: 123 (1992-2019)

\section{PENDAHULUAN}

Remaja adalah masa perubahan dari masa anak menuju dewasa dan perilaku kaum remaja mencoba hal baru yang di dapatnya terutama dari rangsangan seksual. Menurut survei yang diselenggarakan RISKESDAS tahun 2018, sebanyak 39,17 \% setara 2 dari 5 anak perempuan usia 10-17 tahun menikah sebelum usia 15 tahun dan 33,5\% remaja perempuan usia 15-19 tahun sudah hamil. Survei Litbang Kesehatan bekerjasama dengan UNESCO tahun 2018 menunjukkan sebanyak 5,6\% remaja Indonesia sudah melakukan seks bebas pranikah, di Kota Bekasi ada 348 remaja yang melakukan seks diluar nikah (DinKes Kota Bekasi, 2019).

Perilaku seksual remaja dapat berakibat pada penularan HIV/AIDS. Lalu pada kasus terinfeksi HIV 150.000 penderitanya berusia remaja (IDAI, 2018). Di Kota Bekasi kasus HIV mengalami peningkatan secara signifikan, bahkan di Jawa Barat pada tahun 2018 dan menduduki peringkat ke 2 setelah Kota Bandung, salah satu penyebab utamanya adalah pola hidup masyarakat yang tidak sehat, terutama pola pergaulan bebas. Sepanjang tahun 2019, tercatat virus HIV menginfeksi 335 jiwa melalui seks bebas di Kota Bekasi (Dinkes Kota Bekasi, 2019). Remaja mendapatkan informasi seksual melalui tayangan video porno sekitar $97 \%$.
Usia 15-19 tahun sebanyak 12,5 juta orang mengakses internet. Survei terhadap 4.500 siswa dan siswi SMP dan SMA di 12 kota hampir $97 \%$ mengakses konten pornografi hasil survei KPAl di tahun 2018. Hasil dari wawancara kepada guru kesiswaan di SMK Bhakti Bangsa pada tanggal 27 februari 2020, mengatakan ada siswi mengundurkan diri dari sekolah karena hamil diluar nikah dan 3 kasus terekspos oleh pihak sekolah pada 3 tahun belakangan ini yang berhubungan dengan perilaku seks bebas sehingga murid sekolah SMK Bhakti Bangsa hamil diluar nikah. Survei pendahuluan di SMK Bhakti Bangsa pada 20 murid didapatkan $80 \%$ siswa yang berpacaran dan berperilaku seksual seperti menonton video porno, mereka mengatakan mendapat kesenangan dan kenikmatan tersendiri saat menonton video porno, berciuman serta meraba payudara pasangannya. Berdasarkan uraian diatas perlu dilakukan penelitian terhadap masalah ini " Faktor apa saja yang berhubungan dengan perilaku seksual pada Remaja di SMK Bhakti Bangsa Kota Bekasi tahun 2020.

\section{BAHAN DAN METODE}

Penelitian ini merupakan penelitian kuantitatif deskriptif dengan desain cross sectional karena hanya mengamati hubungan antara variabel bebas dan variabel terikat. Penelitian ini bertujuan mengetahui dan 


\section{Jurnal Bidang IImu Kesehatan}

menjelaskan determinan perilaku seksual pada remaja di SMK Bhakti Bangsa Kota Bekasi Tahun 2020. Penelitian ini dilaksanakan di SMK Bhakti Bangsa Kota Bekasi. Pada penelitian ini populasi nya adalah siswa dan siswi SMK Bhakti Bangsa kelas $X$ sampai kelas XI sebanyak 306 orang. Sampel adalah 174 orang. Teknik pengambilan sampel menggunakan teknik accidental sampling. Kriteria inklusi sampel yaitu siswa-siswi kelas
X - XI SMK Bhakti Bangsa Kota Bekasi yang bersedia menjadi responden serta mengisi kuesioner, sedangkan kriteria eksklusi yaitu siswa atau siswi yang mengundurkan diri menjadi responden dan tidak mengisi kuesioner dengan lengkap.

Teknik analisa data yang digunakan yaitu univariat, bivariat dengan menggunakan chi square, multivariat dengan menggunakan regresi logistik.

\section{Hasil Penelitian}

Tabel 1 Distribusi Frekuensi Karakteristik Remaja

$(n=174)$

\begin{tabular}{lcc}
\hline \multicolumn{1}{c}{ Karakteristik } & $\mathbf{n}$ & $\%$ \\
\hline $\begin{array}{l}\text { Perilaku Seksual } \\
\text { Tidak beresiko }\end{array}$ & 80 & 46,0 \\
$\begin{array}{l}\text { Beresiko } \\
\text { Pengetahuan }\end{array}$ & 94 & 54,0 \\
$\begin{array}{l}\text { Baik } \\
\text { Kurang }\end{array}$ & 61 & 35,1 \\
Media informasi & 113 & 64,9 \\
Beresiko & & \\
Tidak beresiko & 64 & 36,8 \\
Peran orang tua & 110 & 63,2 \\
Tidak & 103 & 59,2 \\
Ya & 71 & 40,8 \\
Pengaruh teman sebaya & & \\
Positif & 70 & 40,2 \\
Negatif & 104 & 59,8 \\
\hline
\end{tabular}

Berdasarkan tabel 1 diatas terlihat bahwa sebanyak $80(46,0 \%)$ responden tidak berisiko dan responden memiliki perilaku seksual yang bersiko dan 94 (54,0\%) responden memiliki perilaku seksual yang berisiko, terlihat bahwa responden yang pengetahuannya baik yaitu $61(35,1 \%)$ dan yang pengetahuannya kurang yaitu 113 (64,9\%), terlihat bahwa responden yang pernah terpapar dengan media informasi berjumlah 64 (36,8\%), sedangkan yang pernah terpapar dengan media informasi yaitu berjumlah $110(63,2 \%)$, terlihat bahwa responden yang tidak mendapat peran orang tua yaitu 103 (59,2 \%) dan yang mendapat peran dari orang tua yaitu sebesar $71(40,8$ $\%)$, terlihat bahwa pengaruh teman sebaya 


\section{Jurnal Bidang Ilmu Kesehatan}

yang postif yaitu $70(40,2 \%)$ dan pengaruh teman sebaya yang negatif yaitu $104(59,8 \%)$.

Diagram 1

Perilaku Seksual pada Remaja

$(n=174)$

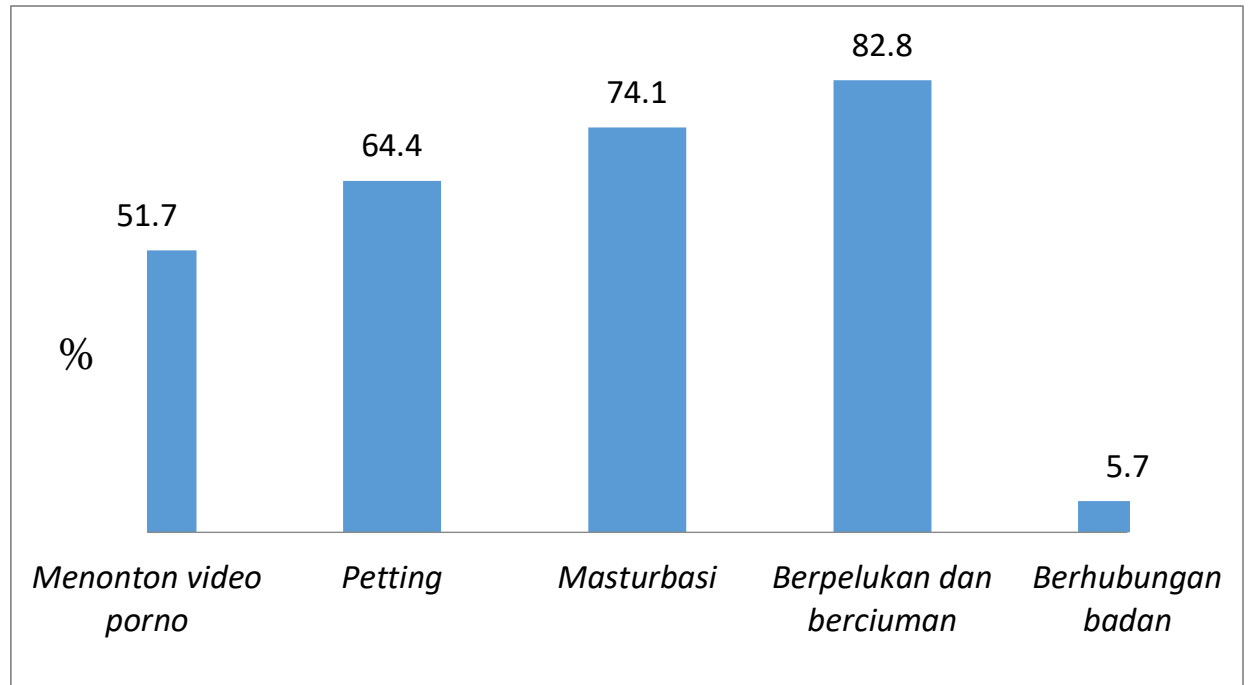

Bahwa responden rata-rata pernah menonton video porno yaitu $51,7 \%$, petting $(64,4 \%)$, masturbasi $(74,1 \%)$, berciuman yaitu $(82,8 \%)$ dan yang melakukan hubungan seksual yaitu $(5,7 \%)$.

\begin{tabular}{|c|c|c|c|c|c|c|}
\hline \multirow{3}{*}{ Variabel } & \multicolumn{4}{|c|}{ Perilaku seksual $(n=174)$} & \multirow{3}{*}{$\begin{array}{c}p \\
\text { value }\end{array}$} & \multirow{3}{*}{$\begin{array}{c}\text { OR } \\
\text { (Cl } 95 \%)\end{array}$} \\
\hline & \multicolumn{2}{|c|}{ Tidak beresiko } & \multicolumn{2}{|c|}{ Beresiko } & & \\
\hline & $\mathbf{n}$ & $\%$ & $\mathbf{n}$ & $\%$ & & \\
\hline \multicolumn{7}{|l|}{ Pengetahuan } \\
\hline Cukup & 36 & $\begin{array}{c}59 \\
0\end{array}$ & 25 & 41,0 & 0,017 & 2,258 \\
\hline Kurang & 44 & $\begin{array}{c}38 \\
9\end{array}$ & 69 & 61,1 & & \\
\hline Jumlah & 80 & $\begin{array}{c}46, \\
0\end{array}$ & 94 & 54,0 & & \\
\hline \multicolumn{7}{|c|}{ Media informasi } \\
\hline Tidak pernah & 39 & $\begin{array}{c}60 \\
9\end{array}$ & 25 & 39,1 & 0,004 & $\begin{array}{c}2,625 \\
(1,393-4,947)\end{array}$ \\
\hline Pernah & 41 & $\begin{array}{c}37 \\
3\end{array}$ & 69 & 62,7 & & \\
\hline Jumlah & 80 & $\begin{array}{c}46, \\
0\end{array}$ & 94 & 54,0 & & \\
\hline \multicolumn{7}{|c|}{ Peran orang tua } \\
\hline Cukup & 41 & $\begin{array}{c}59 \\
9\end{array}$ & 31 & 43,1 & 0,022 & $\begin{array}{c}2,136 \\
(1,156-3,948)\end{array}$ \\
\hline Kurang & 39 & $\begin{array}{c}38 \\
2\end{array}$ & 63 & 61,8 & & \\
\hline Jumlah & 31 & 46, & 36 & 53,7 & & \\
\hline
\end{tabular}




\begin{tabular}{lcccccc}
\hline & $\mathbf{3}$ & & & & \\
\hline Pengaruh teman sebaya & & & & & & \\
Positif & 42 & 60, & 28 & 46,7 & 0,004 & $(1,397-4,857)$ \\
\multirow{2}{*}{ Negatif } & 0 & & & & \\
& 15 & 56, & 66 & 59,5 & & \\
\multirow{2}{*}{ Jumlah } & & $\mathbf{4 6}$ & & & & \\
& $\mathbf{8 0}$ & $\mathbf{0}$ & $\mathbf{9 4}$ & $\mathbf{5 4 , 0}$ & \\
\hline
\end{tabular}

Tabel 2 Hasil Analisis Bivariat Determinan Perilaku Seksual pada Remaja

Berdasarkan tabel 2 telihat bahwa responden dengan pengetahuan cukup tetapi perilaku seksualnya bersiko yaitu berjumlah $25(41,0$ \%), sedangkan responden yang pengetahuannya kurang tetapi perilaku seksualnya tidak beresiko berjumlah $44(38,9$ \%). Uji chi square didapatkan ( $p$ value 0,017 ) artinya ada hubungan antara pengetahuan dengan perilaku seksual remaja. Odds Ratio (OR) $95 \% \mathrm{Cl}=2,258(1,197-4,2622)$ artinya responden yang pengetahuannya kurang tentang perilaku seksual berpeluang 2,2 kali beresiko terhadap perilaku seksual dibandingkan responden yang pengetahuannya cukup. Responden yang tidak pernah mendapat media informasi tetapi perilaku seksualnya beresiko yaitu sebesar 25 (39,1 \%) sedangkan responden yang pernah mendapat media informasi tetapi perilaku seksualnya tidak beresiko yaitu 41 $(37,3 \%)$. Uji chi square didapatkan ( $p$ value $0,004)$ artinya ada hubungan yang signifikan antara paparan media informasi dengan perilaku seksual.

Odds Ratio (OR) 95\% Cl = 2,625 $(1,393-4,947)$ artinya responden yang pernah terpapar media informasi tentang porno berpeluang 2,6 kali berisiko terhadap perilaku seksual dibandingkan responden yang tidak pernah terpapar. Responden yang cukup mendapat peran orang tua tetapi perilaku seksualnya berisiko yaitu 31 (43,1 \%). Sedangkan responden yang kurang mendapat peran orang tua tetapi perilaku seksualnya tidak beresiko yaitu 39 (38,2 \%). Uji chi square didapatkan ( $p$ value 0,022$)$ artinya ada hubungan yang signifikan antara peran orang tua dengan perilaku seksual remaja.

Sedangkan responden yang kurang mendapat peran orang tua tetapi perilaku seksualnya tidak beresiko yaitu 39 (38,2 \%). Uji chi square didapatkan ( $p$ value 0,022 ) artinya ada hubungan yang signifikan antara peran orang tua dengan perilaku seksual remaja. Hasil Odds Ratio (OR) 95\% Cl = 2,136 (1,156-3,948) responden yang kurang mendapat peran orang tua berpeluang 2,1 kali berperilaku seksual beresiko dibandingkan responden yang mendapat cukup peran dari orang tua. Uji chi square didapatkan ( $p$ value 0,118 ), artinya tidak ada hubungan antara jenis kelamin dengan perilaku seksual remaja. Uji chi square didapatkan ( $p$ value 0,216 ) artinya ada tidak ada hubungan antara usia dengan perilaku seksual remaja. Pengaruh teman 
sebaya yang memberi pengaruh positif terhadap responden berperilaku seksual perilaku seksual berisiko yaitu 28 orang $(40,0 \%)$ sedangkan pengaruh teman sebaya yang memberi pengaruh negatif tetapi perilaku seksualnya tidak beresiko yaitu berjumlah 15 (36,5 \%). Uji chi square didapatkan ( $p$ value 0,004$)$ artinya ada hubungan yang signifikan antara pengaruh teman sebaya dengan perilaku seksual remaja. Hasil Odds Ratio (OR) $95 \% \mathrm{Cl}=2,605$ $(1,397-4,857)$ artinya responden yang mendapat pengaruh negatif dari teman sebaya nya berpeluang 2,6 kali beresiko terhadap perilaku seksual berisiko dibandingkan responden yang mendapat pengaruh positif dari teman sebayanya.

Tabel 3

Permodelan Akhir Multivariat

\begin{tabular}{lccccc}
\hline \multicolumn{1}{c}{ Variabel } & \multirow{2}{*}{ B } & P value & OR & \multicolumn{2}{c}{$95 \%$ C.I } \\
& & & & Lower & Upper \\
\hline Media informasi & 0,845 & 0,012 & 2,329 & 1,202 & 4,510 \\
Peran orang tua & 0,701 & 0,032 & 2,016 & 1,061 & 3,833 \\
Teman sebaya & 0,767 & 0,021 & 2,153 & 1,124 & 4,123 \\
\hline
\end{tabular}

Dari tabel diatas yang berhubungan signifikan yaitu media informasi, peran orang tua dan teman sebaya. Hasil uji regresi logistik bahwa remaja yang terpapar media informasi berpeluang 2,3 kali melakukan perilaku seksual yang beresiko setelah di kontrol oleh variabel perang orang tua, teman sebaya dan pengetahuan.

\section{PEMBAHASAN}

Hubungan Pengetahuan dengan Perilaku

\section{Seksual Remaja}

Dalam penelitian ini bahwa Uji chi square didapatkan hasil nilai ( $p$ value 0,017$)$ artinya ada hubungan antara pengetahuan dengan perilaku seksual remaja di SMK Bhakti Bangsa Kota Bekasi. Hasil Odds Ratio (OR) $95 \% \mathrm{Cl}=$ $2,258(1,197-4,2622)$ artinya responden yang pengetahuannya kurang tentang perilaku seks berpeluang 2,3 kali beresiko terhadap perilaku seksual dibandingkan responden yang pengetahuannya cukup. Pengetahuan remaja tentang seksual masih sangat kurang. Faktor ini ditambah dengan informasi keliru yang diperoleh dari sumber yang salah, seperti mitos seputar seks, VCD porno, situs porno di internet dan lainnya yang akan membuat pemahaman serta persepsi anak tentang seks menjadi salah. Selain itu, remaja mempunyai persepsi bahwa hubungan seks merupakan cara mengungkapkan cinta, sehingga demi cinta, seseorang merelakan hubungan seksual dengan pacar sebelum nikah (Setiawan A, 2008). Penelitian ini di dukung oleh WHO yang melakukan survey dibeberapa negara tahun 2016 memperlihatkan adanya informasi yang 
baik dan benar, dapat menurunkan permasalahan reproduksi pada remaja. Sehingga bisa dikatakan remaja dengan tingkat pengetahuan tinggi maka perilakunya semakin baik, karena tindakan seseorang (overt behavior) di bentuk oleh pengetahuan. Meskipun banyak remaja mengetahui tentang seks, akan tetapi faktor budaya yang melarang membicarakan mengenai seksualitas di depan umum karena dianggap tabu, sehingga menyebabkan remaja tidak memiliki pengetahuan lengkap akan seksual, menyebabkan remaja hanya mengetahui cara dalam melakukan hubungan seks namun tidak mengetahui dampak yang akan muncul akibat perilaku seksual tersebut.

\section{Hubungan Media Informasi dengan Perilaku} Seksual

Diperoleh nilai ( $p$ value 0,004 artinya ada hubungan yang signifikan antara paparan media informasi dengan perilaku seksual. Hasil Odds Ratio (OR) 95\% Cl = 2,625 (1,3934,947) artinya responden yang pernah terpapar media informasi tentang perilaku seksual berisiko berpeluang 2,6 kali beresiko terhadap perilaku seksual dibandingkan responden yang tidak pernah terpapar. Hasil penelitian ini sejalan dengan penelitian Rasmiani, dkk (2014), berdasarkan hasil analisis statistik menunjukkan media massa berhubungan dengan perilaku seksual remaja dengan nilai ( $p$ value 0,011). Menurut Sarwono (2010) dalam Saputri (2014) perilaku seksual adalah segala perilaku yang didorong oleh hasrat seksual baik yang dilakukan sendiri dengan lawan jenis maupun sesama jenis tanpa adanya ikatan pernikahan menurut agama. Peran aktif orang tua dalam mencegah perilaku seksual remaja adalah dengan melakukan kegiatan pengawasan terhadap seberapa sering anak mengakses media sosial (bisa ayah dan atau ibu) terhadap anaknya yang berusia remaja berkenaan dengan topik kesehatan repoduksi remaja (Noegroho, 2014). Dapat disimpulkan bahwa peran media massa turut memberikan kontribusi pada remaja untuk melakukan aktifitas seksual dini atau saat ada kesempatan. Di sisi lain kemudahan memperoleh media yang berhubungan pornografi adalah kenyataan yang tidak dapat dihindari, tidak hanya di kota - kota besar pornografi juga dapat diperoleh di pelosok desa tentunya dengan cara yang berbeda.

Variabel yang berhubungan signifikan dengan perilaku seksual remaja yaitu media informasi, peran orang tua dan teman sebaya. Dari analisis multivariat menunjukkan variabel yang paling dominan dalam penelitian ini adalah media informasi yang didapat nilai $O R$ $95 \% \mathrm{Cl}=2,329(1,202-4,510)$ yang artinya responden yang mendapat paparan media informasi perilaku seksual berisiko akan berpeluang 2,3 kali melakukan perilaku seksual yang beresiko. Hasil ini tidak sejalan dengan hasil penelitian Mentari (2011) yang menunjukkan bahwa tidak ada hubungan 
antara sumber informasi dengan perilaku seks bebas pada remaja. Menurut Sarwono (2012), banyak faktor yang mempengaruhi perilaku seksual pada remaja salah satunya media sosial (internet). Hasil penelitian ini sejalan dengan hasil penelitian Zidna (2017) yang menyatakan ada hubungan bermakna antara paparan media sosial dengan perilaku seksual pranikah remaja SMA di kota Semarang.

Keaktifan remaja dalam mengakses sumber informasi terkait perilaku seksual maupun kesehatan reproduksi menjadi asumsi dasar bahwa semakin aktif responden dalam mengakses media informasi, semakin tinggi perilaku seksual berisiko yang akan terjadi pada remaja.

\section{Hubungan Antara Peran Orang Tua dengan Perilaku Seksual}

Uji Chi square diperoleh nilai ( $p$ value 0,022 ) artinya ada hubungan yang signifikan antara peran orang tua dengan perilaku seksual remaja. Hasil Odds Ratio (OR) $95 \% \mathrm{Cl}=2,136$ $(1,156$ - 3,948) responden yang kurang mendapat peran orang tua berpeluang 2,1 kali berperilaku seksual beresiko dibandingkan responden yang mendapat cukup peran dari orang tua. Menurut teori Efendi (2009) fungsi orang tua ialah sebagai pendidik yang juga berfungsi sebagai orang tua adalah komponen keluarga yang terdiri dari ayah dan ibu dan merupakan hasil dari sebuah ikatan perkawinan yang sah untuk dapat membentuk suatu keluarga. Pentingya peran orang tua dalam membentuk prilaku anak, semakin baik peran orang tua dalam memberikan pendidikan khusunya kesehatan seksual maka semakin baik perilaku seksual pada anak. Hasil penelitian ini sejalan dengan penelitian yang dilakukan oleh Sujarwati (2014) menyatakan bahwa, terdapat hubungan yang erat tentang peran orang tua dalam memberikan pendidikan seksual terhadap perilaku seksual pada remaja.

\section{Hubungan Pengaruh Teman Sebaya dengan} Perilaku Seksual

Uji chi square didapatkan nilai ( $p$ value 0,004 ) yang artinya ada hubungan yang signifikan antara pengaruh teman sebaya dengan perilaku seksual remaja. Hal ini sesuai dengan penelitian yang dilakukan Richard (2015) dalam disertasinya yang menyatakan bahwa interaksi sosial di sekolah menengah memiliki efek besar pada inisiasi seksual. Munculnya perilaku seks menyimpang di pengaruhi oleh teman yang tidak baik, keinginan untuk diakui oleh teman sebaya membuat remaja mengambil pilihan yang kurang tepat hanya karena ingin bersama dengan temantemannya, meskipun kadang remaja tersebut menyadari pilihannya kurang tepat. Namun kebutuhan akan pengakuan oleh teman sebaya lebih besar, maka remaja cenderung mengutamakan pilihan teman sebaya ketimbang pilihannya sendiri. Pengaruh teman sebaya sangat kuat sehingga munculnya penyimpangan perilaku seksual 
dikaitkan dengan norma kelompok sebaya. Salah satu pengaruh negatif dari teman sebaya adalah gaya pergaulan bebas. Hal-hal yang dilakukan oleh teman sebaya menjadi semacam acuan atau standar norma tingkah laku yang diharapkan dalam pertemanan, misalnya gaya pacaran teman sebaya menjadi semacam model atau acuan yang digunakan seorang remaja dalam berpacaran.

\section{SIMPULAN}

Paparan media informasi berperan penting terhadap perilaku seksual yang beresiko pada remaja.

\section{DAFTAR PUSTAKA}

Badan Kependudukan dan Keluarga Berencana Nasional. 2019. Badan Penelitian dan Pengembangan Kesehatan 2018 Kesehatan Reproduksi Remaja. Jakarta : Kementrian Kesehatan.

Badan Penelitian dan Pengembangan Kesehatan . 2018. Survei dengan UNESCO Mengenai Remaja Indonesia Melakukan Seks Bebas Pranikah. From KOMINFO: http://kominfo.go.id.

Chadwick S. 2011. Reclaiming Sexual Deviance as Sexual Liberality: A Study of Attitudes, Behaviors and Testosterone. University of Michigan.

Dinas Kesehatan Kota Bekasi. 2019. Data Konseling dan Tes HIV di Kota Bekasi.

\section{SARAN}

Bagi pihak sekolah disarankan agar lebih mengawasi perilaku siswa-siswi untuk bijak menggunakan media informasi ( internet). Penelitian lebih lanjut di perlukan dengan menggunakan metode kualitatif untuk memperoleh informasi yang lebih mendalam tentang perilaku seksual remaja.

Efendi. 2009. Manajemen Pusat Kesehatan Masyarakat. Jakarta : Salemba Medika

Ikatan Dokter Anak Indonesia. 2018. Masalah Penyakit Menular Yang Banyak Dialami Remaja. Jakarta.

Komisi Perlindungan Anak Indonesia. 2018. Status Anak terpapar Pornografi.

Mentari, Wahyu Dewi. 2011. Hubungan Sumber Informasi dan Pengetahuan Tentang Kesehatan Reproduksi Dengan Perilaku Seks Bebas Pada Remaja Di SMP Muhammmadiyah 7 Surakarta. Skripsi. Surakarta: Universitas Muhammadiyah Surakarta.

Noegroho, A., Hariadi, S.S., Priatamtama, P.W. 2014. Komunikasi Orang Tua- Remaja dan Perilaku Preventif Seks Remaja Di 
Kabupaten Banyumas. Jurnal Komunikasi Profetik. 7(2):45-52.

Rasmiani, E,. Irmayani \& Mallo, A. 2014. Faktor-faktor yang Berhubungan dengan Perilaku Seksual Remaja Kelas II di SMA Negeri 8 Mandai - Maros. Jurnal Ilmiah Kesehatan Diagnosis. 5(1):140144.

Ricards-Shubik S. Peer Effects in Sexual Initiation: Separating Deamand and Supply Mechanism (Internet). 6, Quantitative Economics. 2015.

Riset Kesehatan Dasar (RISKESDAS). 2018.

Zidna, Sabela Naja, F. AAgusyahbana, A. Mawarni. 2017. Hubungan Pengetahuan, Sikap Mengenai Seksualitas dan Paparan Media Sosial dengan Perilaku Seksual pada Remaja SMA di Kota Semarang. Jurnal Kesehatan Masyarakat. 5(4):282-293.

Saputri, Yunita Ilhami,. Hidayani. 2014. Faktorfaktor yang Berhubungan dengan
Perilaku Seks Pra Nikah Remaja. Jurnal IImu Kesehatan Masyarakat. 5 (1): 1-62.

Sarwono, Sartilo W. 2011. Psikologi Remaja. Jakarta: PT. Raja Grafindo Persada.

Setiawan, Agus. 2008. Memahami Hubungan Pendidikan Seks Sejak Dini Dengan Perilaku Seksual Pada Remaja. Jakarta : Bharata Karya Aksara.

Stefany, S, Nurbani, Badarudin. Studi Korelasi Penggunaan Media Sosial Pada Pelajar Remaja di Kota Medan. Jurnal Pemikiran dan Penelitian Sosiologi. 2(1):10-31.

Sujarwati. 2014. Peran Orang Tua dengan Sumber Informasi dalam Pendidikan Seks dengan Perilaku Seksual Remaja Pada Masa Pubertas di SMAN 1 Turi. J Ners dan Keb Ind. 2 (3): 112-6.

WHO. 2016. Releases New Fact Sheets on Adolescent Contraceptive Use. Sexual and Reproductive Health, World Health Organization. 